\title{
THE IMPACT OF HUMAN CRITICAL SUCCESS FACTOR ON ERP SYSTEM IMPLEMENTATION
}

\author{
Fasti Herianty Akhzan')*, Grace T. Pontoh' ${ }^{2}$, Arifuddin ${ }^{3)}$ \\ ${ }^{1,2,3}$ Faculty of Economics and Business, Hasanuddin University, Indonesia.
}

\begin{abstract}
Many researchers have investigated the critical success factors in ERP system implementation. The previous study has examined four primary human critical success factors (competence, behavior, team composition, and communication) and based on study literature performed by the author, there were many studies found that top management support also has crucial role in ERP implementation. The objective of this study is to examine the impact of top management support, competence, behavior, team composition, and communication in ERP implementation. This study was conducted in three stages. First, review sources and scientific literature relevant to this research. Second, analyze the findings and recommendations of previous research to determine the component of variable $x$. Third, conduct research using a quantitative approach through a questionnaire survey. Questionnaires were distributed to employees from various company that involved directly in ERP implementation. This study found that all five variables positively correlated to project success and only team composition variable that significantly positively correlated to project success. This study offers ERP project managers the crucial factors needed to be concerned for the project success.
\end{abstract}

Keywords: ERP, Human Critical Success Factors.

\section{INTRODUCTION}

Enterprise Resource Planning (ERP) is an enterprise-wide software solution that integrates and automates business functions of an organization. ERP implementation has been performed by many companies and it gave various results. The successful and the failure of ERP implementation were measured by benefits perceived by the company which is company's performance improvement.

ERP implementation results in substantive changes of accounting information system. These changes were occurred in information preparation and information auditing. Before ERP implementation, the reporting process was manually performed, the report was processed after all data has been received from all departments through the company. With ERP system, the report can be processed soon, at any time.

The effectiveness in generating information by using ERP system can improve manager's ability in analyzing the information. ERP system can provide information at any time when the data is needed. The ability of this integrated system can reduce barrier between functions in the company and give access for managers to obtain information that has not been done before.

${ }^{*}$ Corresponding author. Email address: fastiakhzan@gmail.com 


\section{AFEBI Accounting Review (AAR) \\ Volume 6, No 01 (2021)}

Despite of advantages provided by the ERP system, there were companies that failed in implementing the system. Statistical data from Panorama Consulting Solution showed that until 2012,60\% of companies that used the ERP system has failed to obtain the advantages of the system. This failed was due to various factors which are consultant and vendor, human resource, managerial, project management, process, organization, and technical issue (Amid et al., 2012).

Most of the failures was due to bad selection process that ignored contextual factors of the organization (Uzoka et al., 2008). Organization characteristic has critical role in successful of ERP implementation (Lawalata, 2012). Besides, the successful of ERP implementation also affected by IT resource support (organizational factors) owned by user company (Ifinedo, 2007). Other organizational factor that affected the successful of ERP implementation is incentive system as motivation for user to encourage the quality of information system (Kulkarni et al, 2007).

Sarker and Lee (2003) found that human resource factors also have critical role for the successful of ERP implementation. Human resource factors are related to the perceptions of users that cause users to be reluctant to use information systems that have been developed by the company. The reluctance or refusal of users to adopt or use a new system is one of the reasons for the failure of implementing information systems that companies must pay attention to, because the efforts and cooperation of technicians, companies and end users of the system are very important for the success of the ERP system (Nah and Delgado, 2006). Lack of user acceptance can cause users to just be forced to use without being balanced with reliable use of the ERP system. Besides that, it can also cause dissatisfaction for users with the ERP system.

Petter et al. (2013) conducted a literature study in search of independent variables that affect the success of information systems. The research showed that there are several strong factors that can influence the success of information systems. These factors are then grouped into two groups, namely user and social characteristics and project and organizational characteristics. In the research results, there are five independent variables that have a strong influence on the success of information systems. This study only examines the variables that have a strong influence on the success of information systems according to Petter et al. (2013). The five independent variables that have a strong influence are three variables from user characteristics (comfort, trust, and user expectations of the system) and two variables from organizational characteristics (extrinsic motivation and IT infrastructure of the organization).

Research by Petter et al. (2013) showed the importance of user involvement in planning the implementation of information systems. In practice, planning is usually carried out by top management of the company. Internal factors of the user in the form of comfort (enjoyment), trust, and user expectations of information systems should also be considered for the success of information systems. In addition, organizational factors that support end users, extrinsic motivation and the availability of IT infrastructure provided by the company, also play a role in the success of information systems. Review literature that examines user acceptance of the implementation of information systems in Indonesia is still few and none has included the influence of variables related to individual and organizational contexts to assess end-user acceptance of information systems, especially ERP systems. 
Jenko and Matjaz (2016) have set primary human success factors for ERP system implementation to reduce hundreds of different secondary factors which were set and researched in previous articles into four main groups: competence, behavior, team composition and communication. Based on study literature performed by the authors, we found that top management support is one of the human factors that also has crucial role in ERP implementation. Top management support has already been included in root cause analysis by Jenko and Matjaz in their study and was categorized as secondary factors. The purpose of this study is to examine the impact of the four primary human factors plus one secondary human factor, top management support, as critical success factors to ERP implementation. The results of this study are expected to provide project managers and other stakeholders areas that need to be concerned to prevent the failure in ERP implementation in Indonesia.

\section{LITERATURE STUDY}

Critical success factor (CSF) is management term for elements needed by an organization or project to achieve its mission. This element is an important factor or activity needed to achieve the success of a company or organization (Rockart in Jenko and Matjaz). This concept was first developed by D. Ronald Daniel of McKinsey \& Company in 1961.

Enterprise Resource Planning helps to manage business processes in one integrated unit such as marketing, production, purchasing and storing all transactions in a database that is used by the company and provides management reporting tools.

Ellen Monk and Bret Wanger (2013) define ERP system as a software program that is used by companies to integrate and coordinate information throughout the company's business areas. An ERP program helps manage all existing business processes in a company.

In a study conducted by Jenko and Matjaz (2016), it was stated that several authors (Huang, 2010; Nasir and Sahibuddin, 2011; Ziemba and Oblak, 2013; and Gupta, et al., 2014) classifies Critical Success Factors (CSFs) into three main groups, human factors, organizational factors, and technical factors.

According to Huang (2010), researchers pay more attention to human factors than technical factors in implementing the ERP systems. It was indicated by more articles on end-user involvement and training in implementing ERP systems than articles on technical capabilities or information technology infrastructure.

Jenko and Matjaz (2016) in their research formulated four elements that influence Primary Human Factors (PHFs), which are competence, behavior, communication, and team composition.

According to Beliz and Emrah (2015), who conducted research on success factors of ERP system implementation in construction companies in Turkey, the most significant success factors in ERP system implementation are support and commitment from top management, goals and objectives clear, the competence of the project team, the effectiveness of the project leader, and the cooperative team members.

Zyad, et al (2016) in their study of critical success factors (CSFs) for information technology governance (ITG) found that one of the most important and relevant success factors in implementing ITG is management support. 


\section{AFEBI Accounting Review (AAR) \\ Volume 6, No 01 (2021)}

Linying, et al (2009) in their study entitled Top Management Support of Enterprise System Implementation found that top management support (TMS) is divided into three types which are top management support related to the provision of resources; top management support related to change management; and top management support related to shared vision within the organization.

Christopher and Ben (1999) in their study stated that top management support in implementing an ERP system must ensure that in the organization there is a mutual agreement (consensus) regarding business process change (BPC - Business Process Change). ) as well as ensuring the accuracy of the resources and people involved in the ERP system implementation project.

Toni and Klara (2001) in their stated that ERP implementation is a high-risk project that requires proper management. Organizations must have the ability to identify critical issues that affect the process of ERP system implementation and know when these issues in the ERP system implementation process must be addressed effectively so that the benefits of implementing this system can be perceived by the organization and potential failures can be prevented.

Majed, et al. (2002) in their study states that in Lyytinen and Hirschheim's (1987), IT project success can be seen as the success of correspondence, process, interaction, and success of expectations. Successful interaction is a condition in which user behavior towards IT is positive.

Tsun Chow and Dac-Buu Cao (2007) in their research found that there are three critical success factors in agile software development projects. Agile is a short-term development model that requires rapid adaptation and development to change of any kind. These factors are delivery strategy, agile software engineering techniques, and team capability.

Based on the literature review and the findings and recommendations of previous research described above, the hypotheses proposed are:

$\mathrm{H}_{1}$ : Top management support has positive and significant correlation to the successful of ERP system implementation.

$\mathrm{H}_{2}$ : Compensation has positive and significant correlation to the ERP implementation success.

$\mathrm{H}_{3} \quad$ Behavior has positive and significant correlation to the ERP implementation success.

$\mathrm{H}_{4}$ : Team composition has positive and significant correlation to the ERP implementation success.

$\mathrm{H}_{5}$ : Communication has positive and significant correlation to the ERP implementation success.

\section{RESEARCH METHODOLOGY}

This study uses a quantitative research methodology. This study examines the effect of variable X, human factors (PHFs - Primary Human Factors) as a determining factor for success (CSFs) on variable $\mathrm{Y}$, the application of the ERP system. Variable $\mathrm{X}$ consists of 5 PHFs elements that have been described before, which are:

$\mathrm{X}_{1}$ : Top management support

$\mathrm{X}_{2}$ : Competence

$\mathrm{X}_{3}$ : Behavior 
$\mathrm{X}_{4}$ : Team composition

$\mathrm{X}_{5}$ : Communication

Based on the explanation above, the authors propose the following research model:

Figure 1. Research Model

\begin{tabular}{|l|c|}
\hline \multicolumn{1}{|c|}{ Human Factors: } \\
\hline 1. Top Management Support \\
2. Compentence & \\
3. Behaviour & Success of ERP \\
4. Tim Composition & \\
5. Communication & \\
\hline
\end{tabular}

Source: Researcher

Population in this study are organizations in Indonesia, both private and public sectors. Sampling method used in this study was purposive sampling hence the selected sample of this study were 30 organizations that have been implemented ERP system for no less than 5 years which allowed this study to examine the correlation between human factors and success of ERP implementation.

Data used in this study were primary data which directly collected by researchers from respondents. Data was collected by using questionnaire method which distributed by online questionnaires using google form. Questionnaires were distributed to employees that involved directly in ERP implementation.

Data generated from a survey using questionnaire is statistical data. Therefore, the analysis carried out in this research is descriptive statistical analysis. In this research, the validity test, reliability test, classical assumption test and hypothesis test will be conducted. The hypothesis test will be conducted by using multiple linear regression analysis and determination test.

$$
\mathbf{y}=\mathbf{b 0}+\mathbf{b}_{1} \mathbf{X}_{1}+\mathbf{b}_{2} \mathbf{X}_{2}+\mathbf{b}_{3} \mathbf{X}_{3}+\mathbf{b}_{4} \mathbf{X}_{4}+\mathbf{b}_{5} \mathbf{X}_{5}+\mathrm{e}
$$

$\mathrm{y} \quad$ : successful of ERP implementation

$\mathrm{b}_{0} \quad:$ the value of $\mathrm{Y}$ when all of the independent variables (X1 through $\mathrm{Xp}$ ) are

equal

to zero

$b_{1}, b_{2}, \ldots, b_{5}:$ the estimated regression coefficients

$\mathrm{x}_{1} \quad$ : Top management support

$\mathrm{x}_{2} \quad$ : Competence

$\mathrm{x}_{3} \quad:$ Behavior

$\mathrm{X}_{4} \quad:$ Team composition

$\mathrm{x}_{5} \quad:$ Communication

e $\quad$ : error term

\section{RESULT AND DISCUSSION}

The data used in this study were obtained by distributing questionnaires to respondents which are employees who work in companies both in the private and public sectors in Indonesia (Jakarta, Makassar, Papua) who are in direct contact with the implementation of the ERP system in their organizations. Researchers distributed 40 


\section{AFEBI Accounting Review (AAR)}

Volume 6, No 01 (2021)

questionnaires to 40 respondents and received 34 replies, but only 30 questionnaires could be processed because there were replies more than once by the same respondent.

The data analysis process used in this study used the SPSS 27.0 for Windows program. Before analyzing the data, first the validity and reliability tests were carried out. After the data has been analyzed, researcher discusses the results of the analysis and finally draws a conclusion.

Table 1. Number of Respondents and Distributed Questionnaires

\begin{tabular}{lrr}
\hline \multicolumn{1}{c}{ Description } & Amount & Percentage \\
\hline $\begin{array}{l}\text { Questionnaire } \\
\text { distributed }\end{array}$ & 40 & $100 \%$ \\
Not-replied & & $15 \%$ \\
questionnaire & 6 & \\
$\begin{array}{l}\text { Replied questionnaire } \\
\text { Valid questionnaire }\end{array}$ & 34 & $85 \%$ \\
\hline
\end{tabular}

Source: Researcher

Respondents in this study were company employees, both in the private and public sectors who were in direct contact with the ERP system. To clarify the intended respondents, a table regarding respondents is presented as follows.

a. Based on Division

Table 2. Respondence Based on Division

\begin{tabular}{lrr}
\hline \multicolumn{1}{c}{ Division } & $\begin{array}{c}\text { Number of } \\
\text { Respondent }\end{array}$ & \\
& Amount & $\%$ \\
\hline Finance Accounting & 14 & 47 \\
IT & 5 & 17 \\
Internal Audit & 3 & 10 \\
Sales and Marketing & 1 & 3 \\
Research and Development & 1 & 3 \\
Credit Analysis & 1 & 3 \\
Functional Consultant & 1 & 3 \\
Business Controller & 1 & 3 \\
Customer Relation & 1 & 3 \\
Divisi Migas \& Sistem Pembangkit & 1 & 3 \\
Penjamin Data & 1 & 3 \\
\hline Total & $\mathbf{3 0}$ & $\mathbf{1 0 0}$ \\
\hline
\end{tabular}

Source: Researcher

b. Based on Gender

Table 3. Respondence Based on Gender 


\begin{tabular}{lrr}
\hline \multicolumn{1}{c}{ Description } & \multicolumn{2}{c}{$\begin{array}{c}\text { Number of } \\
\text { Respondents }\end{array}$} \\
& Amount & $\%$ \\
& & \\
\hline Male & 8 & 27 \\
Female & 22 & 73 \\
\hline Total & $\mathbf{3 0}$ & $\mathbf{1 0 0}$ \\
\hline
\end{tabular}

Source: Researcher

\section{Validity Test and Reliability Test}

Based on the table below, the correlation value for the items with the total score is compared with the $r$ table value with a significant 0.05 with a 2 -sided test and the amount of data $(\mathrm{n})=30$, then the $\mathrm{r}$ table is 0.349 , the result of the analysis of the validity of the variable independent and dependent above is greater than $r$ table so it can be said to be valid.

Table 4. Validity Test

\begin{tabular}{|c|c|c|c|}
\hline $\begin{array}{l}\text { Variable / } \\
\text { Indicator }\end{array}$ & $\begin{array}{c}\text { Correlation } \\
\text { Total Item }\end{array}$ & r Tabel & Remark \\
\hline \multicolumn{4}{|c|}{ Top Management Support (X1) } \\
\hline $\mathrm{X} 1.1$ & 0.830 & 0.349 & Valid \\
\hline $\mathrm{X} 1.2$ & 0.914 & 0.349 & Valid \\
\hline $\mathrm{X} 1.3$ & 0.866 & 0.349 & Valid \\
\hline \multicolumn{4}{|c|}{ Compentence (X2) } \\
\hline $\mathrm{X} 2.1$ & 0.745 & 0.349 & Valid \\
\hline $\mathrm{X} 2.2$ & 0.701 & 0.349 & Valid \\
\hline $\mathrm{X} 2.3$ & 0.877 & 0.349 & Valid \\
\hline $\mathrm{X} 2.4$ & 0.896 & 0.349 & Valid \\
\hline $\mathrm{X} 2.5$ & 0.425 & 0.349 & Valid \\
\hline \multicolumn{4}{|c|}{ Behavior (X3) } \\
\hline $\mathrm{X} 3.1$ & 0.851 & 0.349 & Valid \\
\hline $\mathrm{X} 3.2$ & 0.915 & 0.349 & Valid \\
\hline $\mathrm{X} 3.3$ & 0.577 & 0.349 & Valid \\
\hline \multicolumn{4}{|c|}{ Team Composition (X4) } \\
\hline $\mathrm{X} 4.1$ & 0.783 & 0.349 & Valid \\
\hline $\mathrm{X} 4.2$ & 0.872 & 0.349 & Valid \\
\hline $\mathrm{X} 4.3$ & 0.802 & 0.349 & Valid \\
\hline \multicolumn{4}{|c|}{ Communication (X5) } \\
\hline $\mathrm{X} 5.1$ & 0.727 & 0.349 & Valid \\
\hline $\mathrm{X} 5.2$ & 0.859 & 0.349 & Valid \\
\hline $\mathrm{X} 5.3$ & 0.800 & 0.349 & Valid \\
\hline $\mathrm{X} 5.4$ & 0.707 & 0.349 & Valid \\
\hline \multicolumn{4}{|c|}{ Project Success (Y) } \\
\hline Y.1 & 0.791 & 0.349 & Valid \\
\hline
\end{tabular}




\begin{tabular}{llll} 
Y.2 & 0.872 & 0.349 & Valid \\
\hline
\end{tabular}

Source: SPSS 27.0 for Windows

Questionnaire is reliable when the respondent's answer is consistent. A variable is considered as reliable if the Cronbach's Alpha value $>60 \%$. This is because the value of Cronbach's Alpha $>60 \%$ indicates that respondents answered the questionnaire questions consistently. We tested the reliability using SPSS 27.0 for Windows and found the following results.

Table 5. Reliability Test

\begin{tabular}{lrl}
\hline \multicolumn{1}{c}{ Variable } & $\begin{array}{c}\text { Cronbach's } \\
\text { Alpha }\end{array}$ & Remark \\
\hline Top Management Support (X1) & 0.773 & Reliable \\
Competence (X2) & 0.816 & Reliable \\
Behavior (X3) & 0.711 & Reliable \\
Team Composition (X4) & 0.963 & Reliable \\
Communication (X5) & 0.719 & Reliable \\
Project Success (X6) & 0.884 & Reliable \\
\hline
\end{tabular}

Source: SPSS 27.0 for Windows

\section{Classic Assumption Test}

Normality Test

Normality Assumption Testing can be seen through the normal P-P Plot as follow:

Figure 2. P-P Plots

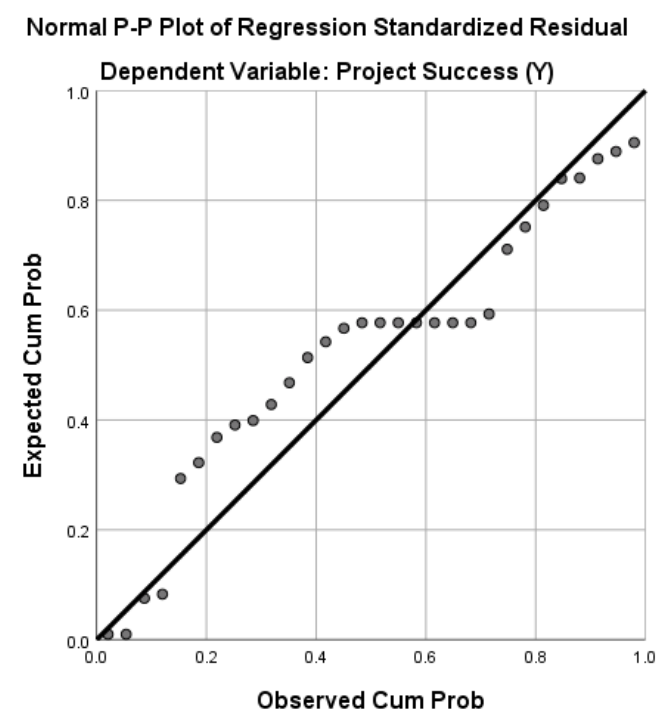

Source: SPSS 27.0 for Windows

The results above show that the regression testing for the effect of top management support, competence, behavior, team composition, and communication on fraud detection can be continued. 
To support the result of normality test using P-Plot, we performed Kolmogorov Smirnov test and the result can be seen as follow:

Figure 3. Kolmogorov-Smirnov Test Result

One-Sample Kolmogorov-Smirnov Test

\begin{tabular}{|c|c|c|}
\hline & & $\begin{array}{l}\text { Unstandardiz } \\
\text { ed Residual }\end{array}$ \\
\hline$N$ & & 30 \\
\hline \multirow[t]{2}{*}{ Normal Parameters ${ }^{a, b}$} & Mean & .0000000 \\
\hline & Std. Deviation & 1.17136068 \\
\hline \multirow[t]{3}{*}{ Most Extreme Differences } & Absolute & .156 \\
\hline & Positive & .131 \\
\hline & Negative & -.156 \\
\hline \multicolumn{2}{|l|}{ Test Statistic } & .156 \\
\hline \multicolumn{2}{|l|}{ Asymp. Sig. (2-tailed) } & $.061^{\mathrm{c}}$ \\
\hline \multicolumn{3}{|c|}{ a. Test distribution is Normal. } \\
\hline \multicolumn{3}{|l|}{ b. Calculated from data. } \\
\hline \multicolumn{2}{|c|}{ c. Lilliefors Significance Correction. } & \\
\hline
\end{tabular}

Source: SPSS 27.0 for Windows

Based on the results in figure 3, it can be seen that the value of Asymp. Sig is 0.061 (greater than 0.05) supporting the P-Plot test result that data has a normal distribution hence the regression testing for the effect of top management support, competence, behavior, team composition, and communication on fraud detection can be continued.

\section{Multicollinearity Tests}

The multicollinearity assumption test is carried out through regression of standardized predicted value with studentized residual regression. Following are the results of the multicollinearity assumption test using SPSS 27.0 for Windows.

Figure 4. Multicollinearity Test

\begin{tabular}{|c|c|c|c|}
\hline \multicolumn{4}{|c|}{ Coefficients $^{a}$} \\
\hline \multirow[b]{2}{*}{ Model } & & \multicolumn{2}{|c|}{ Collinearity Statistics } \\
\hline & & Tolerance & VIF \\
\hline \multirow[t]{6}{*}{1} & (Constant) & & \\
\hline & $\begin{array}{l}\text { Top Management } \\
\text { Support (X1) }\end{array}$ & 0,652 & 1,534 \\
\hline & Competence (X2) & 0,427 & 2,344 \\
\hline & Behaviour (X3) & 0,441 & 2,267 \\
\hline & $\begin{array}{l}\text { Team Composition } \\
\text { (X4) }\end{array}$ & 0,644 & 1,552 \\
\hline & Communication (X5) & 0,367 & 2,728 \\
\hline
\end{tabular}

Based on the results in figure 4, it can be seen in the collinearity statistic column, the VIF column. The VIF value for top management support is 1.534 , competency is 


\section{AFEBI Accounting Review (AAR) \\ Volume 6, No 01 (2021)}

2.344 , behavior is 2.267 , team composition is 1.552 , and communication is 2.728 less than 10.00 and the tolerance variable value for top management support is 0.652 , competency is 0.427 , behavior is 0.441 , Team composition is 0.644 , and communication is 0.367 greater than 0.10 , so it can be concluded that there is no multicollinearity in the regression model.

\section{Heteroskedasticity Test}

Researchers conducted a heteroscedasticity test using SPSS 27.0 for windows and obtained a scatterplot graph as follows.

Figure 5. Scatterplot Graph

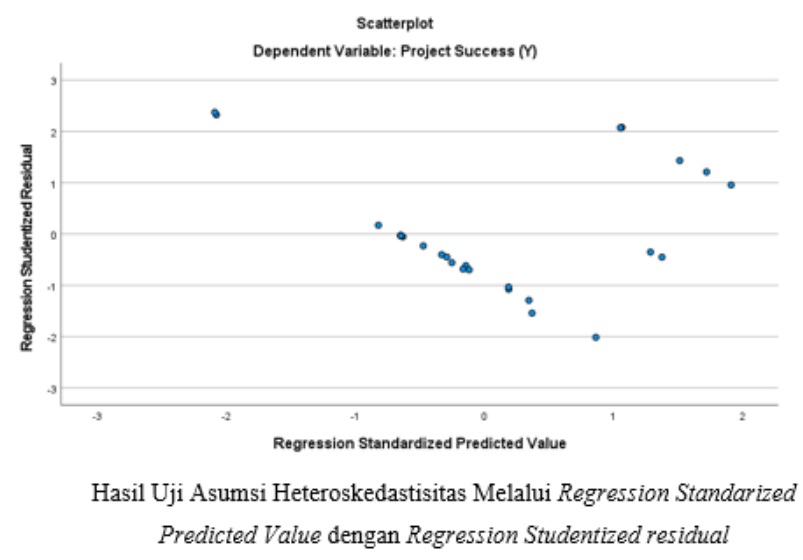

Source: SPSS 27.0 for Windows

The result above show that there are no symptoms of heteroscedasticity in the regression model.

\section{Hypothesis Testing}

Multiple Linear Regression Analysis

This analysis is used to see the extent of top management support, competence, behavior, team composition, and communication on the success of ERP implementation. Details of the regression analysis were processed using the SPPS version 27.0 for Windows computerized program.

Figure 6. Regression Analysis

\begin{tabular}{|c|c|c|c|c|}
\hline \multicolumn{5}{|c|}{ Coefficients $^{a}$} \\
\hline \multirow[b]{2}{*}{ Model } & & \multicolumn{2}{|c|}{ Unstandardized Coefficients } & $\begin{array}{l}\text { Standardized } \\
\text { Coefficients }\end{array}$ \\
\hline & & $\mathrm{B}$ & Std. Error & Beta \\
\hline \multirow[t]{6}{*}{1} & (Constant) & 1,729 & 1,373 & \\
\hline & $\begin{array}{l}\text { Top Management } \\
\text { Support (X1) }\end{array}$ & 0,103 & 0,102 & 0,163 \\
\hline & Competence $(\mathrm{X} 2)$ & 0,053 & 0,088 & 0,121 \\
\hline & Behaviour (X3) & 0,183 & 0,110 & 0,327 \\
\hline & $\begin{array}{l}\text { Team Composition } \\
\text { (X4) }\end{array}$ & 0,143 & 0,065 & 0,354 \\
\hline & Communication (X5) & 0,005 & 0,109 & 0.009 \\
\hline
\end{tabular}


From the table above, the constant value is $\alpha=1.729$ while the coefficient of top management support variable $(\mathrm{X} 1)$ is 0.103 , competence $(\mathrm{X} 2)$ is 0.053 , behavior (X3) is 0.183 , team composition (X4) is 0.143 and communication is 0.005 . From the regression coefficient above, the regression equation is formed as follows:

$\mathrm{Y}=1,729+0,103 \mathrm{X} 1+0,053 \mathrm{X} 2+0,183 \mathrm{X} 3+0,143 \mathrm{X} 4+0,005 \mathrm{X} 5$

The constant value, $\alpha=1.729$, means that, if the independent variable is equal to 0 , then the dependent variable is 1.729 .

$\beta 1=$ Top management support variabel coefficient $(\mathrm{X} 1)$ is 0.103 , this means that if $\mathrm{X} 1$ is increase by $1 \%$, it will increase the success of ERP implementation by $10.3 \%$

$\beta 2=$ The competency variable coefficient (X2) is 0.053 , this means that if $\mathrm{X} 2$ is increased by $1 \%$, it will increase the success of ERP implementation by $5.3 \%$.

$\beta 3=$ The behavioral variable coefficient (X3) is 0.183 , this means that if $\mathrm{X} 3$ is increased by $1 \%$, it will increase the success of ERP implementation by $18.3 \%$.

$\beta 4=$ The coefficient of the team composition variable (X4) is 0.143 , this means that if $\mathrm{X} 4$ is increased by $1 \%$, it will increase the success of ERP implementation by $14.3 \%$.

$\beta 5=$ The communication variable coefficient (X5) is 0.005 , this means that if X5 is increased by $1 \%$, it will increase the success of ERP implementation by $0.5 \%$.

\section{Determination Test}

The determination test shows that the Adjusted R Square value is 0.509. This shows that top management support, competence, behavior, team composition, and communication have 51\% (rounding) effect on the success of ERP implementation and the remaining $49 \%$ is influenced by other variables not examined.

Figure 7. Determination Test

\begin{tabular}{|c|c|c|c|c|}
\hline \multicolumn{5}{|c|}{ Model Summary } \\
\hline Model & $\mathrm{R}$ & R Square & $\begin{array}{l}\text { Adjusted R } \\
\text { Square }\end{array}$ & $\begin{array}{l}\text { Std. Error of } \\
\text { the Estimate }\end{array}$ \\
\hline 1 & $.771^{\mathrm{a}}$ & .594 & .509 & .53951 \\
\hline \multicolumn{5}{|c|}{$\begin{array}{l}\text { a. Predictors: (Constant), Communication }(X 5) \text {, Team } \\
\text { Composition }(X 4) \text {, Top Management Support }(X 1) \text {, } \\
\text { Behaviour }(X 3) \text {, Competence }(X 2)\end{array}$} \\
\hline \multicolumn{5}{|c|}{ b. Dependent Variable: Project Success $(\mathrm{Y})$} \\
\hline
\end{tabular}

Source: SPSS 27.0 for Windows

$t$ Test

To determine the partial effect of each of the independent variables of top management support (X1), competence (X2), behavior (X3), team composition (X4), and communication (X5) on the dependent variable on the success of ERP implementation (Y), then Following are the results of the $t$ test (partial test) using SPSS 27.0 for Windows. 
Figure 8. t Test

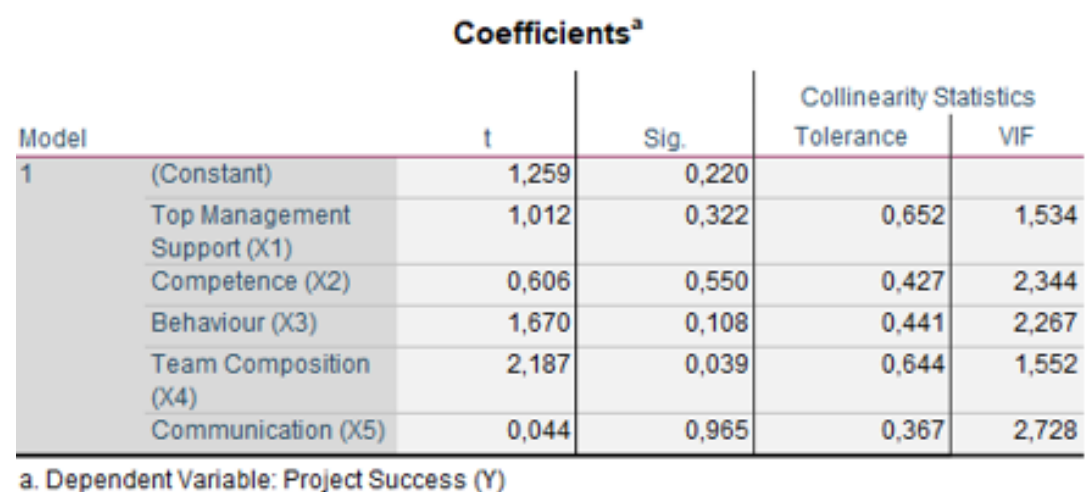

Source: SPSS 27.0 for Windows

a. Top Management Support (X1)

From the calculation of variable $\mathrm{X} 1$, it was found that the perceived value of $\mathrm{t}$ count $=1.012<\mathrm{t}$ table $=2.064$, with a significance level of 0.322 , greater than the level of $\alpha=0.05$. The results of these calculations indicate that the top management support variable (X1) does not have a significant effect on the successful implementation of ERP (Y). Despite of this result, validity test results that we performed before indicate that top management support did have correlation with successful implementation of ERP (Y), hence we can conclude that top management support has impact on successful implementation of ERP but this impact is not significant.

b. Competence (X2)

From the calculation of variable $\mathrm{X} 2$, the perceived value of $\mathrm{t}$ count $=0.550<\mathrm{t}$ table $=2.064$, with a significance level of 0.550 , greater than the level of $\alpha=$ 0.05 . The results of these calculations indicate that the competency variable (X2) does not have a significant effect on the successful implementation of ERP (Y). Despite of this result, validity test results that we performed before indicate that competence did have correlation with successful implementation of ERP (Y), hence we can conclude that competence has impact on successful implementation of ERP but this impact is not significant.

c. Behavior (X3)

From the calculation of variable $\mathrm{X} 3$, the perceived value of $\mathrm{t}$ count $=1.670<\mathrm{t}$ table $=2.064$, with a significance level of 0.108 , greater than the level of $\alpha=$ 0.05. The results of these calculations indicate that the behavioral variable (X3) does not have a significant effect on the successful implementation of ERP (Y). Despite of this result, validity test results that we performed before indicate that behavior did have correlation with successful implementation of ERP (Y), hence we can conclude that behavior has impact on successful implementation of ERP but this impact is not significant.

d. Team Composition (X4).

From the calculation of variable $X 3$, the perceived value of $t$ count $=2.187>t$ table $=2.064$, with a significance level of 0.039 , smaller than the level of $\alpha=$ 0.05 . Based on the results of these calculations, it shows that there is a positive 
and significant influence between team composition (X4) on the successful implementation of ERP (Y), the fourth hypothesis is proven (accepted) and we can conclude that team composition has significant impact on successful implementation of ERP.

e. Communication (X5)

From the calculation of variable $X 5$, the perceived value of $t$ count $=0.044<t$ table $=2.064$, with a significance level of 0.965 , greater than the level of $\alpha=$ 0.05 . The results of these calculations indicate that the top management support variable (X5) does not have a significant effect on the successful implementation of ERP (Y). Despite of this result, validity test results that we performed before indicate that communication did have correlation with successful implementation of ERP (Y), hence we can conclude that communication has impact on successful implementation of ERP but this impact is not significant.

\section{CONCLUSION}

Based on testing and data analysis in this study, it was found that the team composition had a positive and significant effect on the ERP implementation success, while the other four variables (top management support, competence, behavior, and communication) had a positive effect on the successful implementation of the ERP system but not significant. This study has different result from the previous research conducted by Jenko and Matjaz (2016) who found that competence, behavior, and communication also have a positive and significant effect on the successful implementation of ERP systems. This difference might be due to difference in the social, cultural and business environment between Slovenia and Indonesia.

From this study it was also found that top management support, competence, behavior, team composition, and communication had 51\% effect on the success of ERP implementation and the remaining $49 \%$ were influenced by other variables not examined in this study. This is consistent with previous studies which state that humans as one of the critical success factors (CSF) are the most influencing factor for the success of ERP implementation compared to the other two factors, namely organization and technology.

The results of this study provide important determinants of ERP system implementation success that can be of concern to project managers implementing ERP systems in Indonesia to achieve project success.

\section{REFERENCE}

Aleksander Jenko and Matjaž Roblek. (2016). A Primary Human Critical Success Factors Model for the ERP System Implementation. Organizacija, Volume 49:145-160.

Amid, Amin, Moalagh, Morteza, Ahad Zare. (2012). Identification and Clasification of ERP Critical Failure Factors. Information Systems Research, 37(3), 230-234.

Beliz Hozorhon and Emrah Cinar. (2015). Critical Success Factors of Enterprise Resource Planning Implementation in Construction: Case of Turkey. Journal of Management in Engineering. 


\section{AFEBI Accounting Review (AAR)}

Volume 6, No 01 (2021)

Christopher P. Holland and Ben Light. (1999). A Critical Success Factors Model for Enterprise Resource Planning Implementation. IEEE Software.

Galy, Edith, and Mary Jane Sauceda. (2014). Information \& Management Post Implementation Practices of ERP Systems and Their Relationship to Financial Performance. Information \& management 51 (3). Elsevier B.V.: 310-19.

Ghozali, Imam. (2005). Aplikasi Analsis Multivariate dengan Program SPSS. Semarang: BP UNDIP.

Gupta, H., Balakrishnan, R., Rajagopal, S., \& Nguwi, Y. (2014). A Study of Key Critical Success Factors (CSFs) for ERP systems. International Journal of Computer and Information Technology, 3(4), 813-818.

Hall, James A. (2011). Sistem Informasi Akuntansi, Edisi 4. Jakarta: Salemba Empat.

Huang Z. (2010). A compilation research of ERP implementation critical success factors, Issues in Information systems, 11(1), 507-512.

Ifinedo, P. (2007). Interaction Between Organizational Size, Culture, and Structure and Some IT Factors in The Context of ERP Success Assessment: an Exploratory Investigation. The Journal of Computer Systems, 47: 28-44.

Jonathan Arvidsson and Daniel Kojic. (2017). Critical Success Factors in ERP Implementation, The Perspective of the Procurement System User. International Business School, Jonkoping University.

Lawalata, Victor. (2012). Pengaruh Karakteristik Organisasi Terhadap Keberhasilan Implementasi Sistem ERP. Jurnal ARIKA, 6(1).

Linying Dong, Derrick Neufeld, \& Chris Higgins. (2009). Top management support of enterprise systems implementations. Journal of Information Technology Palgrave Macmillan, 24: 55-80.

Majed Al-Mashari, Abdullah Al-Mudimigh \& Mohamed Zairi. (2002). Enterprise resource planning: A taxonomy of critical factors. European Journal of Operational Research, 146:352-364.

Monk, Ellen \& Bret Wagner. (2013). Concepts in Enterprise Resource Planning. Forth Edition. USA: Course Technology and Cengage Learning.

Nah, Fiona Fui-Hoon \& Santiago Delgado (2006) Critical Success Factors for Enterprise Resource Planning Implementation and Upgrade. Journal of Computer Information Systems, 46: 5, 99-113.

Nasir, M.H.N., \& Sahibuddin, S. (2011). Critical success factors for software projects: A comparative study, Scientific Research and Essays, 6(10), 2174-2186.

Nasution, Mustafa E. \& Hardius Usman. (2007). Proses Penelitian Kuantitatif. Lembaga Penerbit Fakultas Ekonomi Universitas Indonesia: Jakarta.

Nazillah, S. Peranan Gadget Terhadap Motivasi Menggunakan Sistem Akademik dengan TAM (Studi kasus Mahasiswa Fakultas Teknik Prodi Teknik Informatika. Media Jurnal Informatika, 7(2): 43-49.

Petter, S., Delone, William H. Ephraim W. (2013). Information Systems Succes. The quest for the independent Variables. J Journal of Information Systems, 29(IV), 761. 
Rockart, J. (1979). Chief executives define their own data needs, Harward Business Review, 57(2), 81-93.

Sarker and Lee. (2003). Using a Case Study to Test the Role of Three Key Social Enablers in ERP Implementation. Information \& Management, 40: 813-829.

Tanzeh, Ahmad. (2009). Pengantar Metode Penelitian. Yogyakarta : Teras.

Toni M. Somers \& Klara Nelson. (2002). The Impact of Critical Success Factors across the Stages of Enterprise Resource Planning Implementations. Proceedings of the 34th Annual Hawaii International Conference on System Sciences.

Tsun Chow \& Dac-Buu Cao. (2007). A survey study of critical success factors in agile software projects. The Journal of Systems and Software, 81:961-971.

Utomo, Y \& D. A. Walujo. (2018). Penerapan Konstruk Technology Acceptance Model pada Layanan Mobile Application di PDAM SuryaSembada. Jurnal Teknik Waktu, 16(1): 39-48.

Uzoka, Faith Michael, Abiola, Richard. (2008). Organizational on ERP Acquistion Using in Extended Technology Acceptance Theory. Internasional Journal of Interprise Information Systems, 4(2), pp. 67-83.

Wibisono, Arif Fajar. (2013). "The Impact ERP System Implementations on Earning Managemet and Timelines Financial Statement (Empirical Studies on Adopters SAP in Indonesia Stock Exchanges), "106-16"

Yuliandewi, P. R., K. Agustini \& M. A. Pradyana. (2016). Analisis Penerimaan Sistem Absensi dengan Menggunakan TAM Studi pada SMK Negeri 1 Singaraja. Kumpulan Artikel Mahasiswa Pendidikan Teknik Informatika,5(2): 1-9.

Ziemba, E., \& Oblak, I. (2013). Critical Success Factors for ERP Systems Implementation in Public Administration, Interdisciplinary Journal of Information, Knowledge and Management, 8, 1-19.

Zyad Alreemya, Victor Chang, Robert Walters, \& Gary Wills. (2016). Critical success factors (CSFs) for information technology governance (ITG). International Journal of Information Management, 36: 907-916. 